\title{
Pakpak Dairi Dance Innovation Learning by E- Learning Schoology in FBS UNIMED Dance Education Product Students
}

\author{
Sitti Rahmah ${ }^{1}$ \\ $\{\underline{\text { rahmaiyen7@gmail.com }\}}$ \\ Faculty of Language and Arts, Universitas Negeri Medan, Indonesia ${ }^{1}$
}

\begin{abstract}
This study aims to produce a product for developing E Learning Schoology learning media for Pakpak Dairi Dance Technique which is applied to students of Dance Education Study Program, as well as knowing the feasibility of E learning Schoology media as a learning innovation. This research approach uses research development (R\&D), which is carried out through stages namely: preliminary research, development planning, media production/development, and media evaluation. The subjects of this study were students of Dance Education Study Program. Respondents in this study involved 36 people, consisting of 2 validators, 3 students for one-on-one trials, 6 students for small group trials, 25 students for field trials. Aspects assessed are the media elearning schoology and aspects of learning. Data analysis is carried out quantitatively to evaluate products, and for other data conducted qualitatively. The results of the study showed that the learning media of E Learning Schoology of Pakpak Dairi Dance Technique was feasible and could be applied to students of Dance Education Program at FBS UNIMED in individual lectures.
\end{abstract} Keywords: Learning Innovation, E-Learning Schoology, Pakpak Dairi Dance
Technique

\section{$1 \quad$ Introduction}

Pakpak Dairi Dance Technique Learning is one of several dance courses in North Sumatra, which must be followed by UNIMED FBS Dance Education Study Program students. In addition, students also study Nusantara dances, and international / international. The provision of this material is of course to prepare prospective educators to have diverse regional, national and international dance knowledge and skills.

The Pakpak Dairi dance technique is given to students in semester 4 with a weight of 2 credits. Students are required to have Pakpak Dairi dancing skills with good and right techniques, and can make performance as a final evaluation. In the learning process, the method used in the class has been carried out still using the imitative method, and is felt to be ineffective and time-efficient. Lecturers as learning resources in subjects that are practical in providing movement technique material in meetings in class.

Learning through E-Learning is intended to answer the challenges of today that education must be able to align with the needs of the 4.0 industrial revolution. Related to this, the researcher attached the word learning innovation in this study with the intention that learning the Pakpak Dairi Dance Engineering course would later be designed with a new strategy 
through E-Learning Schoology. Rogers (1983: 11) gives a limitation which is meant by innovation is an idea, practice, or object object that is considered new by someone or another adopter group. The word "new" is very relative, it can be because someone just found out, or it could be because they just want to accept even though they have long known. Kotler (1996), mentions innovation as something that is pleasing to the goods, services, or ideas that are felt by someone, even though the idea has long existed but this can be said to be an innovation for people who just saw or felt it.

Basically learning Dance will be more interesting when using various media and methods, in fact in the implementation of learning the lecturer has difficulties in the use of media, especially those related to the use of e-learning. If dance practice learning can be carried out by utilizing technology, of course many potential students can be improved, especially in empowering student skills, paying attention to the various potential intelligences and intelligence of students (multiple intelligency), and having advantages in time efficiency.

The purpose of this research is to produce products for developing E-Learning media that can be used in the learning process of the Pakpak Dairi Dance Engineering course that is effective and efficient. In this learning process students can learn the basic dance techniques of Pakpak Dairi dance through the presentation of material that has been prepared in the form of visual and audio visual uploaded on the network. The stages of learning are arranged in accordance with the RPS each meeting, students follow the directions of activities that must be done in PBM contained in e learning schoology Through this e-learning schoology learning students can learn dance material not tied to face-to-face time in class, but learning can take place outside lecture hours.

By conducting learning innovations that utilize Shology's e-learning technology, it will certainly provide many benefits for students, especially in empowering skills, multiple intelligence abilities and also for lecturers. The results of this innovation are expected to provide benefits including:

1. Economically, if the learning of Pakpak Dairi Dance Technique based on e-learning is an option, it will save time and money because learning can be done quickly and within the campus environment itself, which can save energy and finance. Thus computer information technology-based teaching materials in this case blog, youtube, and hand out are a necessity for students to support independent learning; learn without being bound by time and space, so that it can maximize its competencies to be able to understand lecture material more comprehensively. Can help students in receiving and understanding learning materials so that they can improve learning achievement.

2. Familiarize students with exercises using technology tools to operate e-learning as a learning medium for various purposes of their studies. E-Learning is learning that utilizes or implements ICT, both used online with internet and offline facilities with intranet facilities, namely local networks (LAN). Thus it can make learning more interesting / enjoyable so that all students are motivated to actively learn.

3. Motivate lecturers to use E-Learning so that learning becomes more interesting and not boring.

4. Assist lecturers in explaining learning material with technology utilization.

5. Motivate lecturers to increase computer and internet use on campus.

6. Providing new learning media for institutions, especially Education Study Programs UNIMED FBS.

7. Adding a collection of learning media, especially dance practice subjects.

8. The results of this study can also be used as one of the inspirations in conducting learning innovations in other courses in an effort to improve the quality of learning. 


\section{Discussion}

This research is a development research oriented to the development and validation of media products. The product developed in this study is the learning media of Pakpak Dairi Dance Technique, namely by packing learning material with audio visual utilization which contains the dance practice material "TatakTintoaSer-Ser" for the learning of 4th semester students at UNIMED FBS Dance Education Study Program. The learning design model and development procedure carried out are through the stages:

1. Making audio-visual media learning the practice of tataktintoa dance ser-ser in VCD form.

2. Development of e-learning schology media follows procedural steps

3. Developing e-learning schology media devices into products

4. Trial to obtain a number of information that is important for revision purposes.

a. Perform a modular test (testing the course of the program) to ascertain whether the results are as desired until they become a learning medium.

b. Evaluate the products developed.

Product development is based on the analysis of learning needs, characteristics of students, learning environment, and the carrying capacity of technology, both software and hardware. The software used in e-Learning uses the Moodle-based LMS application program provided by http://www.keytoschool.com. Basically, the application software is run on the Keytoschool server. Software supporting moodle server applications, such as Apache, MySQL, and PHP no longer need to be installed, because through hosting (registering) the developer has got a domain (website name) and learning settings service facilities for free.

The model of E-Learning media development in this study refers to Borg \& Gall (1983: 772), can be described in the picture:

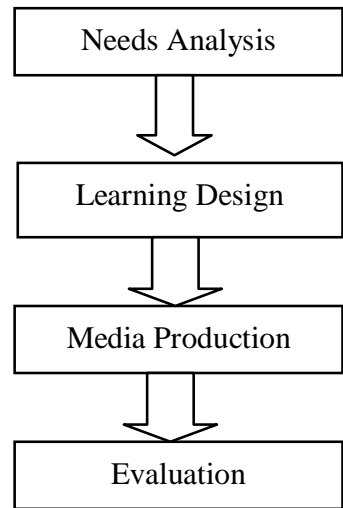

Fig. 1: E-Learning Media Development Model 


\section{Product Development Procedures For E-Learning Media For Pakpak Dairi Dance Technique}

\subsection{Needs Analysis}

Literature study was conducted to gather information, by studying the syllabus of courses at UNIMED FBS Dance Education Study Program students related to the characteristics of the course, the time allocation available, then reading books about Pakpak Dairi culture, supporting books as theoretical study material, journals or research report on the development of E-Learning media.

Competence in the course syllabus is that students are able to understand the various Pakpak Dairi cultures, and that they can dance Pakpak Dairi with good and correct techniques. Each dance material is given to students for 8 times face-to-face with evaluation of their movements. At the end of the lecture students practice individually and in groups that present a variety of floor designs. This lecture is presented in theory $10 \%, 75 \%$ practice, and $15 \%$ field. The forms of teaching and learning activities are demonstrations, imitations, guided training, and independent assignments. Evaluation is done through individual tasks (process assessment), group assignments, and practices.

References used by researchers, namely references from books related to the media, books about lectures, books on E-Learning, books on dance, and other reference books that can be used as research references. Other references are references from the internet, references from existing learning media, references from educational journals, and research results related to learning media.

The field study was conducted by conducting lectures in the previous semester which still used imitation / imitation methods. The use of LCDs in theoretical lectures, using videos as dance appreciation, and classical demonstrations to provide basic motion material for students.

Based on the needs analysis, researchers tried to make computer and internet assisted lecture media as an alternative solution to the problem of the Pakpak Dairi Dance Engineering lecture. The trials in this study selected 25 odd semester students with serinte dance / tatak material to be developed using the e-learning schoology program.

\subsection{Learning Design}

At this stage the researcher analyzes the concepts and tasks related to the material, namely by preparing all teaching materials related to Pakpak Dairi Dance, RPS, Worksheets, 6 Assignments, and flowcharts. The flow chart is a guideline for making storyboard display display plans in making e-learning media products as follows: 


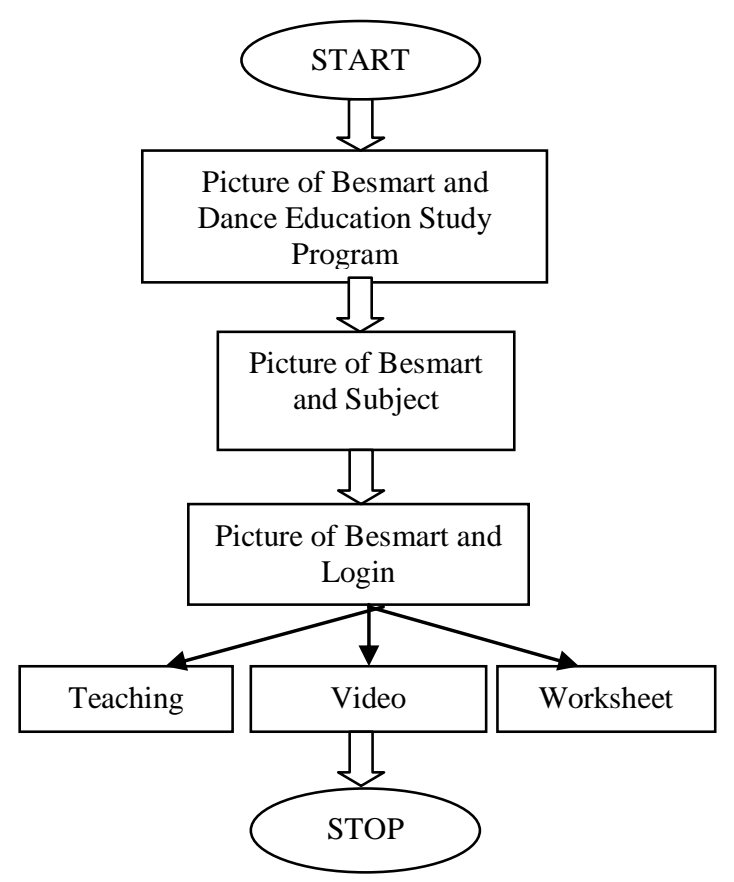

Fig. 2: E-Learning product

\subsection{Media Production}

The first step is to determine the application software that will be used, namely e learning schoology. Furthermore, the writer makes or selects graphics, prepares texts and other supporting materials that have been prepared at the design stage, selected and assembled into a form of e-learning. So that the e-learning assembly runs effectively and efficiently, at every stage of the evaluation. The development of e-learning media is made as a tool in classical or independent lectures. This e-learning media product is packaged in the form of theory and practice which was uploaded to Be Smart e-learning FBS UNIMED and linked to youtube that can be run with computer specifications equipped with internet networks. The data obtained were analyzed quantitatively and qualitatively.

Broadly speaking, the lecture material component of Pakpak Dairi Dance Technique includes: course descriptions, Introduction to Pakpak Dairi Cultural Knowledge, explanation of basic motion techniques of tataktintoaser-ser, names of various dance movements and meaning of motion, description of worksheets, and forms of 6 assignments and evaluation.

\subsection{Evaluation}

This product evaluation phase refers to the opinion of Dick \& Carey (2005: 279); Sadiman et al (2006: 181), namely: a). Validating products to media experts and material experts, followed by data analysis, and product revisions based on review of media experts and material experts, b). Conduct one-on-one trials (one to one), which is 3 students, followed by data analysis, and product revisions based on the results of one-on-one trials. The next trial was small group evaluation on 6 students followed by data analysis, and product revision 
based on the results of small group trials. Then the final trial was a field trial on 25 students, followed by data analysis, and product revision based on the results of the trial so as to produce the final product.

Before the product was tested on students, the product that had been developed was validated by 1 media expert and 1 material expert. This expert validation is important to get assurance that the initial product developed is worth testing for students. Media experts provide assessments, comments, and suggestions on products from aspects of display and programming. Meanwhile, material experts provide assessments, comments and suggestions on products from aspects of learning and content or material. After the product was declared feasible by media experts and material experts, the trial was then carried out by students.

The results of the trial analysis to students through these 3 stages, it can be concluded that the media product lectures of the Pakpak Dairi Dance Technique the product development results in terms of media aspects and aspects of the lecture get a "good" value. This program is very helpful for students in learning the material, easy to understand, and aspects of the presentation of the program interesting to learn. This media is more appropriately used individually and there is no revision in both appearance and material.

\section{Conclusion}

The results of the research and development of Pakpak Dairi Dance Engineering learning innovation through e learning schoology can be concluded that:

1. Procedure for developing innovation in learning Dance Technique Pakpak Dairi for students of Dance Education Study Program at Unibed FBS through e-learning media to produce appropriate media products through steps: (a) conducting needs analysis, (b) developing design, (c) conduct learning media production, (d) conduct evaluation/validation.

2. Learning media for e-learning schoology The Pakpak Dairi dance technique developed is suitable for use as a learning medium based on the results of good media expert validation, and the expert category validation is very good.

3. The results of the assessment of students of the Unimed FBS Dance Education Study Program through the trial 3 stages each provide an assessment of the appearance of the product and an assessment of the presentation of the material is said to be good.

4. This development is precisely carried out in response to the needs of the 4.0 industrial revolution in universities by utilizing Information Technology (IT) in learning that can be implemented in an independent learning strategy.

\section{References}

[1] Clark, R., Mayer, R.E., 2003.Teaching and the web: e-Learning principles and the science of instruction.Taken on August 28, 2009 from http://www.luthersem.edu/mshore/carg-02/principles.htm. [2] Conrad, K., Training, Link., 2000. Instructional design for web-based training.HRD Press.Amherst.

[3] Ceriati., 2016, Audio Visual Punch Dance based on Class X Students in State 4 Tanjungbalai Vocational Middle School. S-1 Thesis SendrtasikUnimed.

[4] Clifford, M., Wilson, M., 2000.Contextual teaching, professional learning, and student experiences: lesson learned from implementation.Taken on January 13, 2008 from http://www.cew.wisc.edu/teachnet. 
[5] Jazuli, M., 2016.Educational Dance Learning Model for Semarang Elementary/MI Students.In the journal www.academia.edu. Downloaded on May 31, 2017

[6] Komalasari, Heni.,2009. Educational Dance Learning Model Application at SDN [7] Nilem Bandung.In the UPI Didactic Methodical Journal Volume April 2009 Edition. Downloaded on May 31,2017

[9] Rahmah, Sitti., 2015. Introduction to Pakpak Dairi Traditional Art Knowledge.Unimed Press

[10] Rogers, E.M., 1983. Diffusion of Innovations. The Free Press, A Division of Macmillan Publishing Co. Inc.New York.

[11] Sardiman, A.M., 2007. Interaction and motivation for teaching and learning.Raja Grafindo Persada. Jakarta.

[12] Yetti, Elindra.,Juniasih, Indah., 2016. The Implementation of Educational Dance Learning Models to Improve Early Childhood Kinesthetic Intelligence Through Active Learning Methods (Development of Models in the Kindergarten Labschool Jakarta in Group B). In the Early Childhood Education Volume 2 Issue 2, November 2016.Downloaded on May 31, 2017. 